\title{
Moving Beyond 'Shut up and Learn'
}

\section{CHRIS WATKINS}

ABSTRACT This article analyses the sort of classroom talk that leads to effective learning, and some of the forces which operate against such practices. It starts with an analysis of the classroom context and the dominant patterns of interaction. These cause processes of learning to be hidden. It then develops by an analysis of effective learning, comprising four headings: active, collaborative, learner-driven and learning-focused. Under each heading important forms of classroom talk are analysed, and principles are offered for developing improved practice.

\section{The Context and the Dominant Patterns}

There's nothing quite like a classroom. It's one of the most crowded situations on the face of the planet, and one of the busiest - teachers can be involved in a thousand interactions a day. This might help us understand why so much (unexamined) talk about classrooms focuses on 'control'. And the effect on classroom learning processes is very substantial. When classrooms were invented 5000 years ago boys from privileged Sumerian families were learning cuneiform writing: the teacher inscribed syllables into the first rows of tablets of clay, the boys then had to inscribe their version, after which the teacher corrected their attempt, turned the tablet over and did some more. That form of relationship is described as the IRE cycle - Initiation-Response-Evaluation - and research of the last fifty years continues to find it as a dominant pattern in current classrooms in countries all over the world (Bellack et al, 1966; Camden, 2001). Its most compressed example is 'Six sixes?' 'Thirty-six.' 'Good girl.'

In the United Kingdom recent decades have seen a reversion to this picture. Observational studies of interaction in primary school classrooms captured the effects of the introduction of the 'National' 'Curriculum'. Galton et al (1999) concluded that it 'appears to have resulted in an increase in the traditional secondary style of teaching, creating a one-way communication system where, for most of the time, teachers talk and pupils sit and listen' (p. 34). 


\section{Chris Watkins}

And in secondary schools, the Campaign for Learning organised a MORI survey of 2500 pupils which included the question, 'Which three of the following do you do most often in class?' Results over a decade showed a large increase in listening to the teacher talking (see Figure 1).

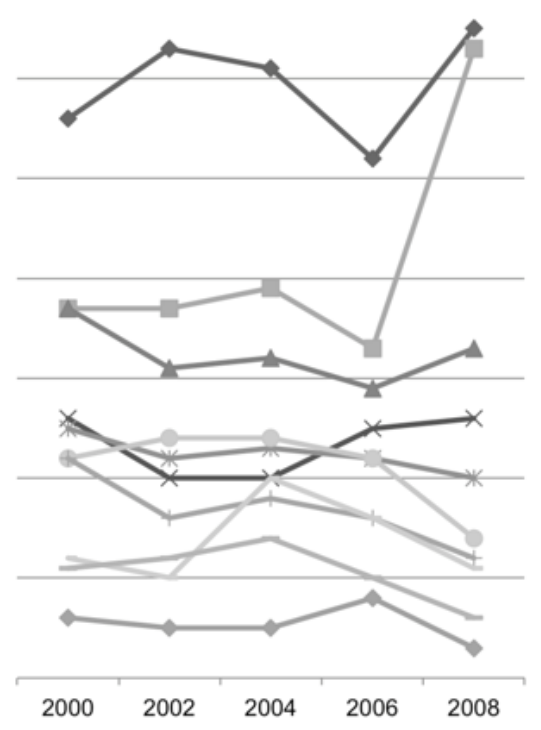

$\neg$ Copy from the board or a book

- Listen to a teacher talking for a long time

- Have a class discussion

$\leftarrow$ Take notes while my teacher talks

*Work in small groups to solve a problem

Spend time thinking quietly on my own

-Talk about my work with a teacher

Work on a computer

Learn things that relate to the real world

$\leadsto$ Teach my classmates about something

Figure 1. Percentage of pupils choosing each of the 10 items as the three most often done in class.

I do not know of a research source to explain this change, but when I ask teachers they point to the 'National Strategies'. Existing theories of classroom change do not easily explain that development. How could someone (in an office in Reading, I'm told) write classroom procedures, put them into folders, and have them sent around England and teachers do it? The explanation is that it conforms to the stereotype of a teacher.

The overall effect is that learners' experiences as learners are hidden. After four decades of studies of classroom learning issues using hidden microphones and video cameras, Nuthall's final (2007) book was given the title The Hidden Lives of Learners. But even in the current culture, which emphasises 'performance', there is evidence that those who succeed in classrooms are those who (hidden to their teachers) exercise self-control and are effective in self-talk. A major study found that 'different areas of self-regulation could explain $34 \%$ of variance of school performance in the primary school, about $21 \%$ in the secondary school and nearly $14 \%$ in the university education' (Volkmann \& Licardo, 2010, p. 267). This is one of the largest effects from a single variable, yet it is a variable that is mostly hidden in the lives of classrooms, and it is 
having a significant effect. Those learners who learn self-regulation from other contexts of their lives are the ones who succeed in teacher-driven systems. I would expect there to be a correlation with social class.

The largest meta-analysis of research on classrooms (over 50,000 studies) was given the title Visible Learning (Hattie, 2008). Its core message was that classroom achievement is highest 'when teachers see learning through the eyes of the student and when students see themselves as their own teachers' (p. 238). How do the key participants come to see things this way? - by talking and listening. Should the book have been titled 'Audible Learning'?

\section{Moving On?}

Moving away from the dominant patterns is not simple, but there is one approach to change which seems successful when the dominant culture is not encouraging: 'appreciative inquiry'. Talk about the best; examine the best; do more of the best. When I have invited teachers to do this about their best experiences of learning in classrooms, they all have experiences to talk about. I have then asked them how much their experiences relate to our first three headings of the research on effective learning - active, collaborative, learnerdriven (Watkins et al, 2007). Some $85 \%$ of them indicate a high rating. So teachers' best experiences accord with decades of research.

1. Active Learning is not merely activity: it is a process of making meaning from activity. Thus, a crucial element is that of talking through the process. A Year 5 class had been working in groups on historical maps of their local area, when we put on each table a diagram of an active learning cycle (Do Review Learn Apply) and asked them to explain to each other what they had just been doing using those headings. The conversation was very striking: engaged, detailed and sophisticated. The teachers went on to use the learning cycle in other contexts to support active reading and active writing. Shortly afterwards I received a batch of letters from that class. Melvyn wrote, 'The cycle to check our reading and writing was a great idea because we usually put nice comments on their work (a) because we didn't want them to be upset, and (b) because we didn't know what to write on it, but now we do know'. Melvyn had made a vital connection to the next heading.

2. Collaborative Learning. In the process of collaboration it is the sharing and exchange of meanings that makes this a learning process. As Annie (10 years old) said in an interview with Caroline Lodge (see Watkins et al, 2007, p. 89): 'You learn more [when working with others] because if you explain to people what to do, you say things that you wouldn't say to yourself, really. So you learn things that you wouldn't know if you were just doing it by yourself. This also hints at the quality of talk which goes on in collaborative learning: it is engaged meaningful talk, not conflict talk or the shouty form of talk currently favoured by the media. Perhaps these distinctions are helped by the poster I used to have on my classroom wall when operating as a learning community (of experienced teachers): 


\section{Chris Watkins}

What sort of conversation for learning?

Dialogue

A conversation, an exchange of ideas or opinions

from Greek dialogs dia $=$ through, logos $=$ speech, word, reason .

Debate

To engage in a formal discussion, dispute or argument.

(Obsolete: To fight or quarrel)

from Old French debatre, to beat; (see batter)

Discussion

A formal discourse on a topic; an exposition.

(Medical: The act of breaking up, or dispersing, a tumour)

from Latin discussion $=$ a shaking, examination

compare percussion, from French percuter $=$ to strike, and concussion!

Exchange of personal meaning talk has also been shown to achieve the development of collaborative skills in the classroom - through review of group work experiences, rather than more teacher telling (Baines et al, 2008).

3. Learner-driven Learning describes the sort of classroom processes which support learner agency and the development of self-regulated learners. As a nine-year-old in a Surrey school said to me when explaining why she enjoyed such a process: 'We could use what we wanted to, to find our own information. We didn't like have to go to one place and do learning on just that particular thing: We got to choose where we went to learn'.[1] The exercise of choice is a first step; the next is to talk over your choices and what else you notice about the journey you have taken. This supports the development of self-talk so that future journeys are more self-monitoring and self-correcting. Georgia (10 years old, talking to Alexia Slutzkin, a teacher), summarised this heading: 'It's the teacher's job to let the learner be the centre of their world'.

The heading 'learner-driven learning' and the idea of learners driving the learning brings us everyday phrases to support talk about it. These include 'hands on the wheel', including the metaphor of learning journey, as outlined below:

Before starting:

Where do we want to get to?

Which way should we go?

Has someone got a map?

Or shall we make up our own route?

Is there anything to remember from previous journeys?

On the road:

How's it going?

Are we on track?

Do we need to change direction?

Shall we check back on the map? 
Has anyone gone another way?

Cor look!

Journey's end:

Where did we get to?

Is this the place we planned? Maybe it's better!

Shall we take a photo/send a postcard?

Did anyone get here by another route?

How would we do it another time?

Where next?

Our first three headings represent the shift from teacher-centred classrooms to learner-centred classrooms, which is a necessary prerequisite for the subsequent shift, the development of learning-centred classrooms. That is where a fourth heading comes in.

4. Learning-centred Learning is explicitly focusing on the experience and understanding of learning, in order that learners develop the metacognitive capacity which is crucial for them to be able to transfer skills across situations. It has to beware of reverting to a teacher-centred stance: 'Let's teach them more about their learning', 'Let's tell them how to be better learners'. The contradictions inside these statements can take a while to spot. Adding a language of learning when the participants' identities are not those of learners is unproductive - they can leave pupils thinking 'hallo, teacher's been on a course'.

Bruner (1985) helps us also beware the sort of talk of 'learning styles', which soon becomes categorical talk of learn-er styles; he helped us see the distinction between narrative and paradigmatic modes of thought. A paradigmatic way of understanding involves the use of general theories, and formal systems based on categorisation such as 'learning styles', which has been shown to have weak theoretical foundations, dubious measurement protocols and overblown claims (Coffield et al, 2004). The contrast is a narrative way of understanding, which is more particular, time-sensitive, and involves human action and intent, and is the version which humans use to talk with each other about their experiences.

Learning-centredness involves a variety of talk about learning, which is rare in the typical classroom. In some schools it is also rare to talk about pupils as learners: this misses an opportunity. I was asked to lead a session with fiveyear-olds in a school near Birmingham. I had only joined their class once before, and had sat at the back. When introduced, I said: 'Very good to see you again. Of course if I've only been in your classroom once before, I know very little about you, but I do know one great thing that applies to everybody in this room - you're great learners!' The eager joyfulness in their faces and body language were clear evidence that they had a very positive image of this noun.

We also need to handle the various forms of talk which hijack the space we might wish to give to learning, and we have to address these in order to 
reclaim the space (Dainton, 2005; Watkins 2006). I have three main candidates: teaching, performance, work (Watkins, 2003). On the last one, a head teacher of one of the Leeds schools involved in a project to support the development of learning-centred schools decided to have a whole-school assembly where she said 'From today on, no more work, only learning'. She reported that Year 1 children ran back to their classrooms excitedly enquiring, 'Is it true? Is it true?' So the verb is also attractive.

Classroom practices can involve:

- making learning an object of attention - Noticing learning;

- making learning an object of conversation - Talking about learning;

- making learning an object of reflection - Reviewing experiences of learning;

- making learning an object of learning - Experimenting with learning.

All of these can be promoted in a story form of language, and here again, appreciative inquiry provides an approach to development. I have witnessed many occasions of people talking to each other about their best experiences of learning, from five-year-olds to school inspectors, and I have never witnessed any examples of disputational talk: it is always engaged, diverse and respectful. It provides an important element in the building of a discourse of learning, which I have described as noticing, narrating, navigating (Watkins, 2015a).

Scaffolds which may be used to capture the experience and to help analyse include 'Storyboards' [2], a simple structure where learners can draw and write about the beginning, middle and end of a learning experience, and extract key elements that made it successful.

On a broader level, the gathering of pupils' views about learning is rare, but the results are dependable. The largest research project on teaching and learning in recent decades showed the following: (1) pupils' responses were characterised by a constructive focus on learning, consensus about what helps learning, and differences in articulacy; (2) pupils agreed that interactive teaching for understanding, contextualising learning in appropriate ways, fostering a stronger sense of agency and ownership, and arranging social contexts amenable to collaborative learning were all helpful to the learning; (3) teachers tended to respond positively and were reassured by the insightfulness of pupil ideas (McIntyre et al, 2005, p. 149).

Even in the context of online learning, recent evidence using Knowledge Forum (Scardamalia, 2004) shows that learners who are supported in talking up a meta-perspective on their processes demonstrate richer understanding, greater complexity of meaning, and more connected online discourse than those who are not supported in this way (Resendes et al, 2015).

I will close with two points which connect to the understanding of the classroom situation made at the start. The power of the situation was highlighted recently when I saw a notice saying, 'Do You Need to Talk?' If this had been in a classroom context, I would have viewed it as the act of a clever teacher trying to get less talk and more quiet. But it was in a doctor's reception and was an invitation to talk more via counselling. The other situation is the 
orchestra. We can think of a teacher's role as orchestrating talk in the classroom; an important point from this metaphor is that when an orchestra is performing, the only person who makes no noise is the conductor.

My experience with schools which develop a learning-centred approach is that 'results' improve, especially for those schools serving underprivileged populations, and the culture change shows in greater adult-style engagement. The only approach which gives excellence and equity is learning-centred (Watkins, 2015b).

\section{Notes}

[1] See video clip 5 at http://chriswatkins.net/classroom-videos/

[2] See presentation 5 at http://chriswatkins.net/presentations/

\section{References}

Bellack, A.A., Kliebard, H.M., Hyman, R.T. \& Smith, F.L. (1966) The Language of the Classroom. New York: Teachers College Press.

Baines, E., Blatchford, P. \& Kutnick, P. with Chowne, A., Ota, C. \& Berdondini, L. (2008) Promoting Effective Group Work in the Primary Classroom: a handbook for teachers and practitioners. London: Routledge.

Bruner, J.S. (1985) Narrative and Paradigmatic Modes of Thought, in E. Eisner (Ed.) Learning and Teaching the Ways of Knowing. Chicago: University of Chicago Press.

Camden, C.B. (2001) Classroom Discourse: the language of teaching and learning, 2nd edn. London: Heinemann.

Coffield, F., Moseley, D., Hall, E. \& Ecclestone, K. (2004) Should We Be Using Learning Styles? What Research Has to Say to Practice. London: Learning and Skills Research Centre.

Dainton, S. (2005) Reclaiming Teachers' Voices, FORUM, 47(2), 159-168. http://dx.doi.org/10.2304/forum.2005.47.2.5

Galton, M., Hargreaves, L., Comber, C., Wall, D. \& Pell, T. (1999) Changes in Patterns of Teacher Interaction in Primary Classrooms: 1976-96, British Educational Research Journal, 25(1), 23-37. http://dx.doi.org/10.1080/0141192990250103

Hattie, J. (2008). Visible Learning: a synthesis of over 800 meta-analyses relating to achievement. London: Routledge.

McIntyre, D., Peddler, D. \& Rudduck, J. (2005) Pupil Voice: comfortable and uncomfortable learnings for teachers, Research Papers in Education, 20(2), 149-168. http://dx.doi.org/10.1080/02671520500077970

Nuthall, G. (2007) The Hidden Lives of Learners. Wellington: New Zealand Council for Educational Research.

Resendes, M., Scardamalia, M., Bereiter, C., Chen, B. \& Halewood, C. (2015) Grouplevel Formative Feedback and Metadiscourse, International Journal of ComputerSupported Collaborative Learning, 10(3), 309-336. http://dx.doi.org/10.1007/s11412-015-9219-x 


\section{Chris Watkins}

Scardamalia, M. (2004) CSILE/Knowledge Forum, in A. Kovalchick \& K. Dawson (Eds) Education and Technology: an encyclopedia, pp. 183-192. Santa Barbara: ABCCLIO. http://www.knowledgeforum.com

Volkmann, K.B. \& Licardo, M. (2010) How Cognitive, Metacognitive, Motivational and Emotional Self-regulation Influence School Performance in Adolescence and Early Adulthood, Educational Studies, 36(3), 259-268. http://dx.doi.org/10.1080/03055690903180376

Watkins, C. (2003) Learning: a sense-maker's guide. London: Association of Teachers and Lecturers.

Watkins, C. (2006) When Teachers Reclaim Learning, FORUM, 48(2), 121-129. http://dx.doi.org/10.2304/forum.2006.48.2.121

Watkins, C. (2015a) Metalearning in Classrooms, in D. Scott \& E. Hargreaves (Eds) SAGE Handbook of Learning, pp. 321-330. London: SAGE.

Watkins, C. (2015b) Developing Learning-centred Classrooms and Schools, in M. Myhill \& R. Maclean (Eds) International Handbook on Life in Schools and Classrooms: past, present and future visions. Dordrecht: Springer.

Watkins, C., Carnell, E. \& Lodge, C. (2007) Effective Learning in Classrooms. London: Paul Chapman/SAGE. http://dx.doi.org/10.4135/9781446211472

CHRIS WATKINS is an emeritus reader in education at the University of London Institute of Education. Recently retired, he has been an independent project leader with schools focusing on learning, and founder of the MA in Effective Learning. Correspondence: c.watkins@ioe.ac.uk; Resources for developing learner-centredness at http://chriswatkins.net 